\title{
Concentration of Heavy Metals in Some Animal Meats from Merowe-City-Sudan
}

\author{
Mawia Hassan Elsaim, 1, ", Aisha Abdelrhaman ${ }^{1}$ \\ ${ }^{1}$ Department of Chemistry, College of Science and Technology University of Merowe Technology, Merowe, Sudan \\ ${ }^{2}$ Department of Chemistry, College of Science, Beijing University of Chemical Technology, Beijing, China
}

Email address:

maelsaimhu7@gmail.com (M. H. Elsaim), maelsaimhu@yahoo.com (M. H. Elsaim)

${ }^{*}$ Corresponding author

\section{To cite this article:}

Mawia Hassan Elsaim, Aisha Abdelrhaman. Concentration of Heavy Metals in some Animal Meats from Merowe-City-Sudan. International Journal of Colloid and Surface Science. Vol. 4, No. 1, 2019, pp. 13-16. doi: 10.11648/j.css.20190401.13.

Received: March 26, 2019; Accepted: April 29, 2019; Published: May 27, 2019

\begin{abstract}
This study was to determine the concentrations of essential metals such as namely Copper, Cobalt, Manganese, Iron and Zinc) and heavy metals such as Cadmium and Lead performed by atomic absorption spectrophotometer (AAS) in two sample of some animal meats of Mutton (sheep) and Beef (cow), collected from the district popularly in Merowe-city, north Sudan. The essential metals estimation in the investigated samples indicated the following range of concentration (0.19 $0.28 \mathrm{mg} / \mathrm{kg}$ ) for Cobalt, $(0.36-0.31 \mathrm{mg} / \mathrm{kg}$ ) for Copper, $(3.16-5.44 \mathrm{mg} / \mathrm{kg})$ for Iron, $(0.12-0.15 \mathrm{mg} / \mathrm{kg})$ for Manganese, and $(5.30$ $7.6 \mathrm{mg} / \mathrm{kg}$ ) for Zinc respectively. These concentrations of essential metals are in the range of human necessities. The concentration of toxic metals (Cadmium and lead) in two samples is not mean detected. The results also showed that were significant differences of some essential elements concentrations $(\mathrm{Mg} / \mathrm{kg})$ in two samples. Generally meat of Beef was found to have to highest significant levels of metals and the meat of Mutton lowest levels. The concentration of Iron and Zinc concentration in all samples were within the tolerance limits.
\end{abstract}

Keywords: Heavy Metals, Meats, Animals, AAS, Sudan

\section{Introduction}

Metals are found in all living organisms where they play a variety of roles. Metals such as $\mathrm{Fe}, \mathrm{Cu}, \mathrm{Mg}, \mathrm{Co}$, and $\mathrm{Zn}$ are essential for human body but chronic metabolic disturbances may occur due to the deficiency or excess of these metals [1]. It is important to keep the level of these metals in their proper ranges for maintaining proper metabolic functions in human body. It can be done by taking selected foods in daily diets from a list which can give information about the metal contents of different foods [2]. Non-essential elements such as $\mathrm{Pb}, \mathrm{Cd}, \mathrm{Cr}, \mathrm{Ni}$, and As are considered to be toxic and their presence in the body can cause profound biochemical and neurological changes in the body [3]. The sources of toxic metals in the environment are the fossil fuels mining industries, waste disposals and municipal sewage, farming and forestry also contribute to the metal content in the environment due to the use of fertilizer pesticide and herbicides. As a consequence of environment pollution, the contaminants may enter the body chain. We are taking food for living. So the major route of entry of most metals into the body is through the diets. Animal meats, meat products and eggs are consumed largely by the general people. Since they contain proteins, amino acids, minerals and vitamins. It is very essential to know the toxic metal contents in food stuffs we are consuming every day. Heavy metals are metals that have density five times more than water density. These metals are permanent which mean they are not consumed by human body through the food chain. The most effect heavy metals are lead mercury, Arsenic, Cadmium, and Aluminum, on human healthiness. These metals get into human body by many manner, such smiling, eating, and can be absorbed by skin. These metals have no beneficial effect to our body; however, they are directly physiological toxic effects at lower level to the body. Heavy metals incorporate or store in living tissues [4]. A result of study, which is done by john and Jeanne [5] showed that arsenic, Cadmium, mercury, and Lead levels are above the permissible levels and very high in numerous tissues of goats lead is neurotoxin and metabolic poison which can bind to vital enzymes and some other 
cellular components lead toxic effects can be seen on nervous, haemo poetic, renal systems, and gastrointinal. Cadmium can be found in food which is considered as the principle environmental sources for it $[4,6]$. Concentration of Cadmium turn out to be more and more as moving via food chain, concentration increases by a factor of approximately, 50 to 60 times as it approaches the carnivores. Cadmium has toxic effects of such as kidney dysfunction hypertension hepatic injury and lung damage $[5,7]$. Nowadays, there is widespread concern about human health from risk of heavy metals that present in food product. Processing technology in the food production increase the probabilities of pollution the food with heavy metals. Eating of polluted food by animals give rise to precipitation of deposit in meat. Study show that higher levels of metals have been indicated in mutton and beef, as cattle graze on contaminated in soil [8]. Level of lead and cadmium was reported by [9], in meat product higher than recommended limits. Meat is considered as the convenient and richest source of nutrients. Where, meat chemical composition depends on feeding animals, as the kind and degree of chemical element, the necessity of inorganic compounds determine by physiological state, feed intake, living condition as well as age [10]. Since the pollution with heavy metals is toxicity, bio magnification, and bio accumulation in the food chain, it is a serious hazard [11]. Has described the toxic effects of metals in animal which was under relatively low levels of metals exposure, disruption of trace element metabolism is one of the earliest effects [12]. In addition, meat contamination with heavy metals is concern for both human health and safety since these metals at relatively minute concentrations are natural toxicity [13]. The objective of this study is carried out to determine the levels of heavy metals such as $\mathrm{Pb}$ and $\mathrm{Cd}$ as well as essential metals such as $\mathrm{Fe}, \mathrm{Cu}, \mathrm{Mn}, \mathrm{Co}$ and $\mathrm{Zn}$ in meats of beef and mutton obtained from Merowe city north Sudan.

\section{Material and Methods}

\subsection{Sample Collection}

Fresh meats sample beef (cow) and mutton (sheep) collected from slaughter popularly in Merowe city north Sudan. The samples were collected and keep ice cold and transported to the laboratory for analysis.

\subsection{Sample Preparation}

$10 \mathrm{gm}$ from each product was taken in to small beaker the beaker was placed in muffle furnace and dried shed at $55 \mathrm{C}^{\circ}$ for 5 hour then cold. $10 \mathrm{ml}$ of concentrated $\mathrm{HCl}(20 \%)$, was added to the obtained ash and dissolved in $10 \mathrm{ml}$ of demonized water and the solution was filtered in $50 \mathrm{ml}$ conical flask using filter paper, the digested sample was quantitatively into $50 \mathrm{ml}$ volumetric flask and then the volume was completed $50 \mathrm{ml}$ with distilled water.

\subsection{Determination of Concentration in Sample}

The determine of $\mathrm{Cd}, \mathrm{Co}, \mathrm{Cu}, \mathrm{Fe}, \mathrm{Mn}, \mathrm{Pb}$, and $\mathrm{Zn}$ in meat of Mutton and Beef were directly on each of the final solutions using Analyst 2018 Atomic Absorptions Spectrophotometer (AAS).

Table 1. Element Wavelength (nm) Slit (nm) Relative Noise Characteristic (mg/l) Characteristic Check (mg/l) Linear Range (mg/l)

\begin{tabular}{lllllll}
\hline Element & Wavelength (nm) & Slit (nm) & Relative Noise & Characteristic (mg/l) & Characteristic Check (mg/l) & Linear Range (mg/l) \\
\hline $\mathrm{Cd}$ & 228.8 & 0.7 & 1.0 & 0.028 & 1.5 & 7.0 \\
$\mathrm{Co}$ & 240.7 & 0.2 & 1.0 & 0.012 & 4.0 & 3.0 \\
$\mathrm{Cu}$ & 324.8 & 0.7 & 1.0 & 0.077 & 6.0 & 2.5 \\
$\mathrm{Fe}$ & 248.3 & 0.2 & 1.0 & 0.11 & 2.0 \\
$\mathrm{Mn}$ & 279 & 0.2 & 1.0 & 0.052 & 2.0 & \\
$\mathrm{~Pb}$ & 283.3 & 0.7 & 0.43 & 0.45 & 1.0 & 2.0 \\
$\mathrm{Zn}$ & 213.9 & 0.7 & 1.0 & 0.018 & 1.0 \\
\hline
\end{tabular}

Table 2. The obtained concentration $(\mathrm{mg} / \mathrm{kg})$ of metals in meat of Mutton and Beef in (10gm in $50 \mathrm{ml})$.

\begin{tabular}{lll}
\hline element & mutton & Beef \\
\hline $\mathrm{Cd}$ & $\mathrm{ND}$ & $\mathrm{ND}$ \\
$\mathrm{Co}$ & 0.19 & 0.28 \\
$\mathrm{Cu}$ & 0.36 & 0.31 \\
$\mathrm{Mn}$ & 0.12 & 0.15 \\
$\mathrm{Fe}$ & 3.16 & 5.44 \\
$\mathrm{~Pb}$ & $\mathrm{ND}$ & $\mathrm{ND}$ \\
$\mathrm{Zn}$ & 5.30 & 7.60 \\
\hline
\end{tabular}

Table 3. The recommended daily allowance (RDA) and the maximum permissible limit (MPL). For an adult person (19-20) and according international standards.

\begin{tabular}{ll}
\hline Elements & (Mg per day) \\
\hline $\mathrm{Cd}$ & $0.3 \mathrm{mg}$ per day \\
$\mathrm{Co}$ & $1-1.5 \mathrm{mg}$ per day \\
$\mathrm{Cu}$ & $1.5-3.2 \mathrm{mg}$ pe rday \\
\hline
\end{tabular}

\begin{tabular}{ll}
\hline Elements & (Mg per day) \\
\hline $\mathrm{Fe}$ & $10-15 \mathrm{mg}$ per day \\
$\mathrm{Mn}$ & $0.5 \mathrm{mg} / \mathrm{kg}$ \\
$\mathrm{Pb}$ & $0.2 \mathrm{mg}$ per day \\
$\mathrm{Zn}$ & $12-15 \mathrm{mgperday}$ \\
\hline
\end{tabular}

\section{Result and Discussion}

The concentrations of heavy metals in the meat of beef and mutton are as presented in table 1. The levels of heavy metals of Cadmium [Cd] and Lead [Pb] are as presented in figure 1 and 6 are not mean detected in two samples. Generally levels of heavy metals $\mathrm{Cd}$ and $\mathrm{Pb}$ in the meat of Beef and Mutton are very low and this indicates that the investigated samples are safe from Cadmium and Lead toxicity. Cadmium is toxic to virtually every system in the animal body. it is almost absent in the human body at birth, however accumulates with age [14]. Had reported in the kidney liver, that cadmium is 
accumulated over long time. Due to chemical similarities of cadmium with number of minerals mainly $\mathrm{Zn}, \mathrm{Fe}, \mathrm{Cu}$ and $\mathrm{Se}$, Cadmium interacts and competition for binding stage. In addition $\mathrm{Cd}$ can affect $\mathrm{P}, \mathrm{Ca}$ and bone metabolism in both people exposed to $\mathrm{Cd}$ and industrial in general environment [15].

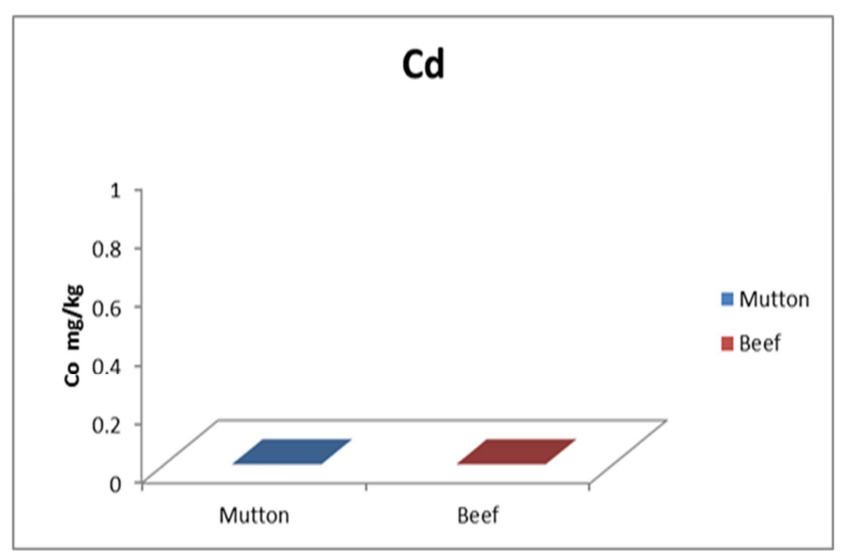

Figure 1. Cadmium Concentration.

Cobalt [Co] levels were observed in the meat of beef and mutton are as presented in figure 2 . The result indicate that the meat of beef $[0.28 \mathrm{mg} / \mathrm{kg}]$ contained the highest. However the mutton meat showed the lest concentration $[0.19 \mathrm{mg} / \mathrm{kg}]$.

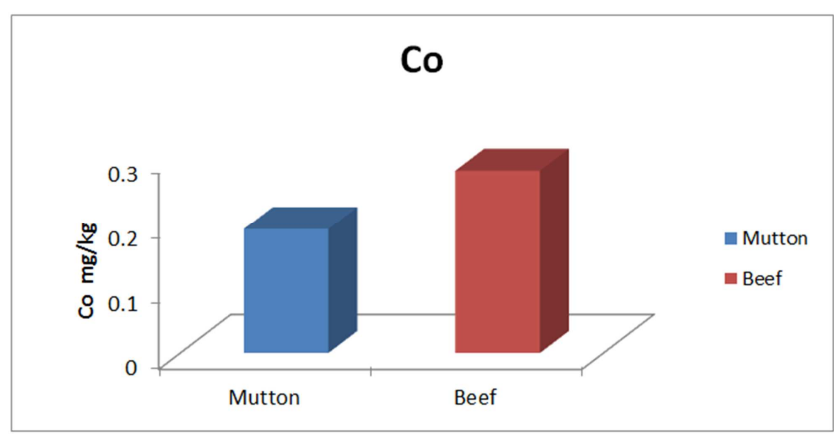

Figure 2. Cobalt Concentration.

The concentration of copper [Cu] were observed in the meat of Beef and Mutton in Figure 3. The highest of $\mathrm{Cu}$ was found in the Beef $[0.36 \mathrm{mg} / \mathrm{kg}]$ and the lowest levels were observed in meat of Mutton [0.31 mg $/ \mathrm{kg}$ ]. Copper plays a key role in human health since it is critical component of different enzyme, bone formation and the integrity of the connective tissue. However, it can lead to health problems for example kidney and liver damage when its levels became high in human body [15]. A although copper is essential element in trace amount but can be toxic. High concentrations of copper as well can be very risk for public health [16] was reported that $10-30 \mathrm{mg}$ of orally consumed copper from foods deposited in copper vessels and could cause headaches, intestinal discomfort and dizziness whereas surplus gathering of copper in liver can consequence cirrhosis or hepatitis or a hemolytic crisis like that seen in acute copper poisoning.

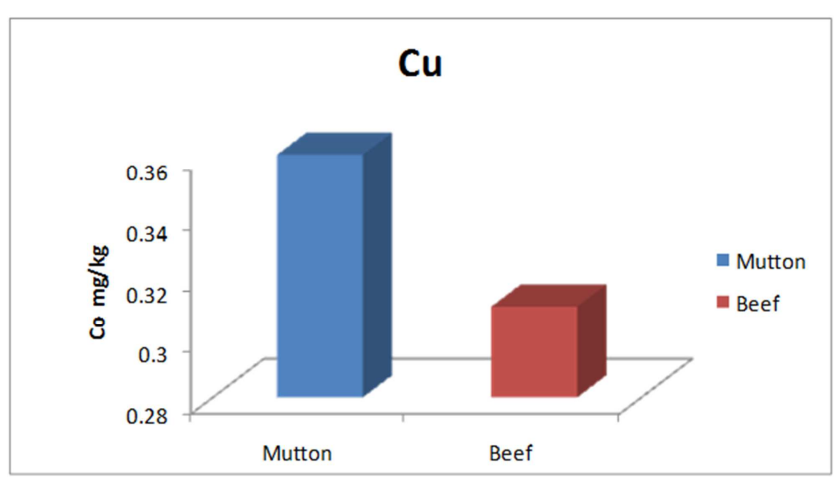

Figure 3. Copper Concentration

The concentration of Iron [Fe] were observed in the meat of Beef and Mutton are as presented in figure 4. The results indicate that the meat of Beef $[5.44 \mathrm{mg} / \mathrm{kg}]$, Co stained the highest than meat of Mutton $[3.16 \mathrm{mg} / \mathrm{kg}]$.

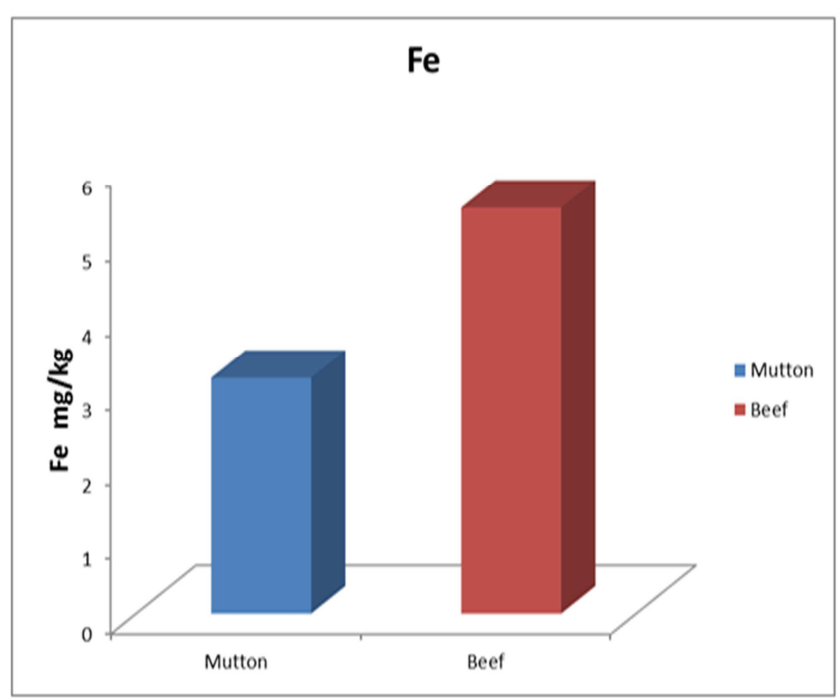

Figure 4. Iron Concentration.

The concentration of manganese $[\mathrm{Mn}]$ in tow samples present in Figure 5. The results indicate that the Meat of Beef $[0.15 \mathrm{mg} / \mathrm{kg}]$ and Mutton $[0.12 \mathrm{mg} / \mathrm{kg}]$, lest concentration compered by international standards $[0.5 \mathrm{mg} / \mathrm{kg}][17]$.

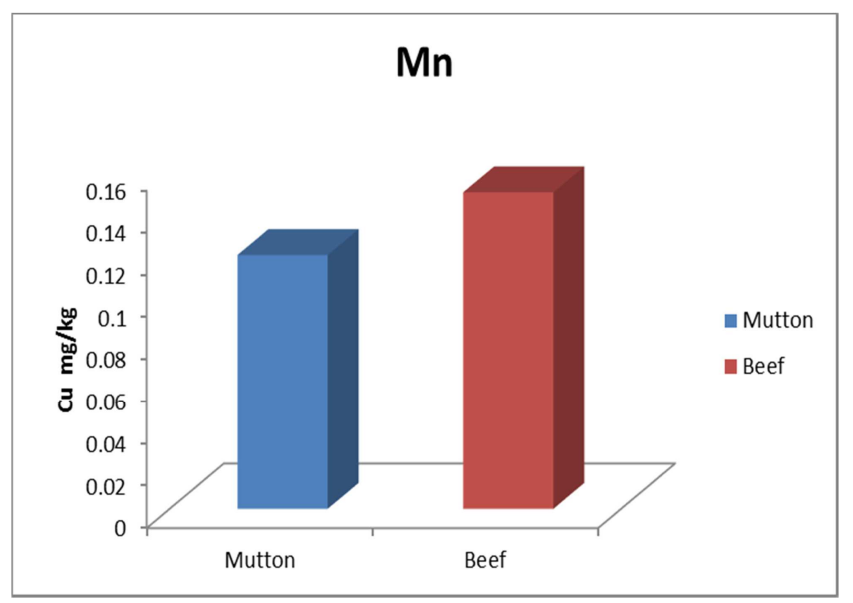

Figure 5. Manganese Concentration. 
The concentration in tow sample not mean detected.

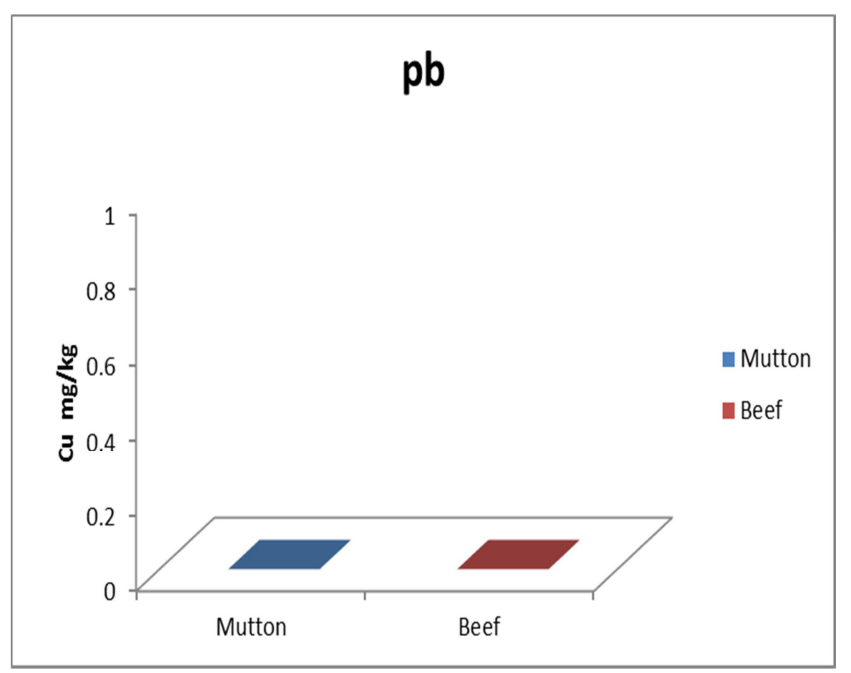

Figure 6. Lead Concentration.

The highest concentration of Zinc was found in meat of Beef $[7.60 \mathrm{mg} / \mathrm{kg}]$. Whereas the lowest of $\mathrm{Zn}$ was found in meat of Mutton $[5.30 \mathrm{mg} / \mathrm{kg}]$. Zinc is an essential trace element for animals, being involved in protein synthesis and as a constituent of many metalloid enzymes.

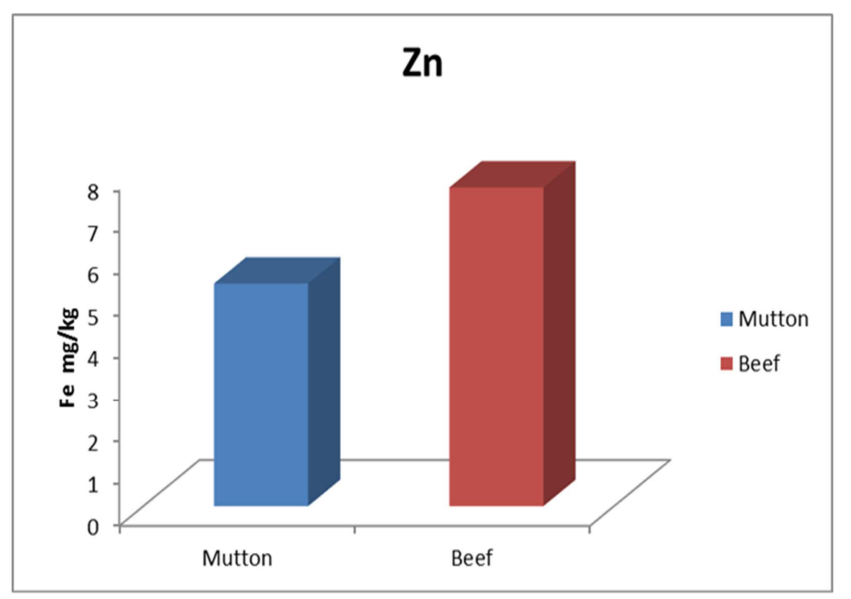

Figure 7. Zinc Concentration.

\section{Conclusion}

The study was done for concentration of heavy metals and to check whether these heavy metals are within the permissible limits set by the World Health Organization (WHO), results of the study confirmed that heavy metals, namely Cadmium (Cd), Cobalt $(\mathrm{Co})$, Cupper $(\mathrm{Cu})$, Iron $(\mathrm{Fe})$, Manganese $(\mathrm{Mn})$, Lead $(\mathrm{Pb})$ and Zinc $(\mathrm{Zn})$, are presence in all the analyzed samples. Generally, beef meat was found to have the highest significant levels of metals and the mutton meat lowest levels. When we compared our result concentration of heavy metals in two sample (beef and mutton), there showed a significant differences. The result also showed that concentration of Cadmium and Lead are not mean detected.

\section{References}

[1] Martz, 1981, The essential trace elements. Science 213, 133237.

[2] Chowdhury, M. Monir Uddin, M, Faridul Alam, M. Reaz Uddin, M. jakir Hossain and M. Z. A Shahidul Alam, Pak. J. Anal. Chem., 2003, 4 (2), 99-103.

[3] Nielsen, F. H Ultra traces elements in human nutrition A. R. Diss, Inc., New York 1982, 379-404.

[4] Baykov, B. D, M. P, Stoyanov and M. L. Gugova, 1996. Cadmium and lead bioaccumulation in male chickens for high food concentrations, toxical. Environ, chem., 54: 155-59.

[5] John, H. H. and I. R. Jeanne, 1994. food Additives, contaminants and Natural toxins. In: Maurice E. S., A. O. James S. L, Moshe and febiger, (Eds.). Modern Nutrition in Health and Disease. 8th Edn., part II, pp: 1597-1598.

[6] Cunningham, W. P. and B. W. Saigo 1997. Environmental science a Global Concern 4th Edn., WMC Brown Publisher, New York pp 389.

[7] Daniel, B, and A. K. Edward 1995. Environmental Science, Earth as living plant. John wiley and Sons New York, pp: 278-279.

[8] Sabir, S. M., S. W. Khan and I. Hayat, 2003. Effect of environmental pollution on quality of meat in district Bagh, Azad Kashmir. Pak. J. Nutr., 2 (2): 98-101.

[9] Gonzalez-Waller D, L. Karlsson. Caballero, F. Hernandez A. Gutierrez, T. Gonzalez -Igalesias, $\mathrm{M}$ Marino and A. Hardissionm 2006 lead and cadmium in meat and meat products consumed by the pollution in Tenerife lslans, Spain, food Addit contamin, 23: 797-793.

[10] Demirezen D. and K. Uruc. 2006 comparative study of trace element in certain fish, meat and meat products. meat Sei., 74: 255-260.

[11] Goyer, R. A. 1997. Toxic and essential metal interactions. Annu. Rev. Nutr., 17: 37-50.

[12] Santhi, D., V. Balakrishnan, A. Kalaikannan and K, T. Radhakirhnan 2008. Presence of heavy metals in pork products in Chennai (India). Am. J. Food Technol, 3 (3): 192-199.

[13] Mahaffey, K. R., 1977. Mineral concentrations in animaltissues: Certain aspects of FDA regulatory role. J. Anim. Sci., 44: 509-515.

[14] Claughlin, M, J, D, R. Parker and J. M. Clarke, 199 Metals and micronutrients, food safety issues, Field crops Res., 60: 143-163.

[15] Atsdr, 2004. Agency for Toxic Substances and Disease Registry, Division of Toxicology, Clifton Road, NE, Atlanta GA. Retrieved from htt/www. atsdr. cdc. gov/toxprofiles /.

[16] Brito G., C. DIAZ, L. Galindo, A. Hardisson, D. Santiago and M. F, Garcia 2005 levels of metals in canned meat products: intermetallic correlations. Bull. Environ contem Toxicology 44 (2): 309-316.

[17] WHO, (World Health Organization), Technical Report Series Evaluation of Certain Food Additivies and contaminants Geneva 1987. Pdf Document (Avaliable in htt//wjqlibdoc.wh,int/ trs/WHO-TRS-751. pdf. 